\title{
The impact of the cost of oral hygiene products on the domestic budget in the urban region of a midsize Brazilian capital city
}

\author{
O impacto do custo de produtos de higiene bucal sobre o orçamento doméstico na zona urbana de uma \\ capital de porte médio Brasileira
}

Thaís Torres Barros DUTRA ${ }^{1}$

André Luis Rodrigues da SILVA'

Alaíse Magalhães CABRAL ${ }^{1}$

José Machado MOITA NETO²

Raimundo Rosendo PRADO JUNIOR ${ }^{1}$

\section{ABSTRACT}

\section{Objective}

To evaluate the impact of the cost of oral hygiene products in Teresina, Piaui, on the Brazilian minimum salary (MS) over the period of two years.

\section{Methods}

The writer of this study visited 12 businesses from five geographical areas of the city during four consecutive months in 2011 and 2013 to collect the prices of toothbrushes, toothpaste, dental floss and mouth rinse solutions of different brands. The prices were used to calculate the monthly expense that one individual would have if they consumed the ideal quantity of the products, as recommended by the dental literature. Brazil's MS at the time of the study was used as a parameter to calculate the impact of the cost of the items on the family budget.

\section{Results}

The mean monthly cost per individual was $R \$ 17.93$ in 2011 (2.88\% of the MS) and $R \$ 24.92$ in 2013 (3.67\% of the MS). There was an increase of $38.9 \%$ in the mean price of products and the impact on the MS increased by $27.43 \%$ during the study period.

\section{Conclusion}

The impact of the cost of the oral care items was high on the Brazilian MS for the studied region. Dentists should be aware that the cost of these products can be an obstacle for their patients.

Descriptors: Medication price. Oral health. Oral hygiene.

\section{RESUMO}

Objetivo

Avaliar o impacto do custo dos produtos de higiene oral em Teresina, Piaúi sobre a o salário mínimo brasileiro ao longo de dois anos de observação.

\section{Métodos}

Doze estabelecimentos comerciais nas zonas geográficas do município foram visitados em quarto meses consecutivos em 2011 e 2013 para coletar o preço de escovas dentais, dentifrícios, fios dentais e antissépticos bucais de diferentes marcas. Para o cálculo do consumo mensal, considerou-se que os produtos foram consumidos em quantidade ideal para o uso. Para o impacto do custo dos itens, o salário mínimo brasileiro na época do estudo foi usado como parâmetro.

\section{Resultados}

O custo mensal médio por indivíduo seria de R\$17,93 em 2011 (2,88\% do salário mínimo) e R\$24,92 em 2013 (3,67\% do salário mínimo).

\section{Conclusão}

Houve aumento de $38,9 \%$ no preço dos produtos e o impacto sobre o SM aumentou em $27,43 \%$ no período do estudo. Os cirurgiõesdentistas devem estar bem informados sobre o custo desses produtos ao prescrevê-los a seus pacientes.

Termos de indexação: Preço de medicamento. Saúde bucal. Higiene bucal.

\footnotetext{
${ }^{1}$ Universidade Federal do Piauí, Programa de Pós-Graduação em Odontologia. Campus Universitário Ministro Petrônio Portella, Ininga, 64049-550, Teresina, PI, Brasil. Correspondência para / Correspondence to: TTB DUTRA. E-mail: <thaistorres.bd@gmail.com>.

${ }^{2}$ Universidade Federal do Piauí, Centro de Ciências da Natureza, Departamento de Química. Teresina, PI, Brasil.
} 


\section{INTRODUCTION}

Oral diseases are a significant worldwide problem and the fourth most expensive disease to treat. In most low and middle-income countries, investment in oral health care is low and resources are primarily allocated to emergency oral care and pain relief ${ }^{1}$.

Recent nationwide surveys on the oral health of the Brazilian population has shown a high caries experience and high prevalence of periodontal disease, despite the fact that both diseases have been gradually decreasing in prevalence and severity ${ }^{2-3}$.

Most oral diseases are linked to unhealthy environments and behaviours, particularly the use of tobacco and excessive consumption of alcohol or sugar. In addition to healthy behaviour, promotion of oral health depends on clean water, adequate sanitation, appropriate exposure to fluoride and proper oral hygiene. Health promotion and measures at individual, professional and community levels are cost-effective in preventing oral diseases ${ }^{1}$

In Brazil, the Unified Health System (SUS) is the public system that provides free oral care to individuals. The aim of SUS's National Policy of Oral Health is to guarantee actions of promotion of oral health, prevention and recuperation of oral health to the entire Brazilian population 4

Prevention of oral diseases requires a multifactorial approach including dietary factors and eating habits, the use of appropriate chemical or mechanical therapy to prevent caries or periodontal diseases and the implementation of effective oral hygiene. Tooth brushing with a fluoride toothpaste is the most important method for delivering fluoride to the tooth surface and to prevent caries. Periodontal diseases can be prevented and controlled through mechanical and chemical means. Conscientious oral hygiene and professional oral cleanings to reduce plaque can prevent or reverse gingivitis, and thus, prevent periodontitis ${ }^{5}$.

Methods for personal oral hygiene include toothbrushing and flossing, which may be augmented by over-the-counter and prescription mouthrinses with antimicrobial action). However, the currently available methods are individually or professionally based and require conscientious oral hygiene practices and regular dental visits ${ }^{6}$. The dentist plays the role of a mentor in this multifactorial approach, and the main objective is achieving an optimum control of dental biofilm, the etiologic agent of the most prevalent oral diseases ${ }^{7}$.

Although the products and tools for these methods are easily available to buy, it is the dentist's responsibility to inform patients about their correct use for the prevention of oral diseases. By informing the population, the dentist is also promoting oral health ${ }^{8}$.

When dentists recommend oral hygiene products to patients, they do not usually take into consideration the impact that the costs of these products have on a family's budget ${ }^{9-10}$. The cost of such items can be an obstacle for individuals who wish to achieve the minimum level of biofilm control that is considered compatible with oral health. Studies have shown an association between socioeconomic status and the adoption of oral health care measures. This might be because low-income individuals neglect to buy some oral hygiene products due to their cost $^{9-10}$.

Therefore, the aim of this study was to analyse the cost of mechanical and chemical oral hygiene products, available in stores in Teresina, Piauí, have on Brazil's minimum salary.

\section{METHODS}

This was a cross-sectional study that evaluated the prices of four oral hygiene items (toothbrushes, toothpastes, dental floss and antiseptic mouth rinse solutions). Data was collected once a month during two four month periods (period 1: March, April, May and June of 2011; period 2: January, February, March and April 2013). This study analysed how these items varied in price from period 1 to period 2 and how this variation compared to the changes in Brazil's minimum salary for the same period.

The businesses for the price collection were randomly selected among major supermarket chains and local pharmacies in the official geographical regions of the city. A total of 12 shops were selected and distributed according to the population of each region. Therefore, three in the north region, three in the east region, two in the south-east region, two in the south region and two in the central region were selected.

The products were selected based on the following criteria: a) they were the best-selling product for their manufacturer, according to information obtained from sales personnel of each shop; b) they had characteristics considered ideal by dental literature ${ }^{11-13}$ (toothbrushes with soft bristles and a small edge; toothpastes with a minimum concentration 
of fluoride of 1,000 ppm and maximum concentration of 1,500 ppm and mouthwash solutions without alcohol).

Before collecting the price of the products, each item was removed from the shelf and checked regarding the above-mentioned characteristics. The prices and the date of collection were then recorded on a form and the product was photographed for future investigations. Items that were not found, were recorded as "product unavailable". In order to limit the number of products to be part of the study, the researcher decided to include 22 items: six toothbrushes, six toothpastes, five dental flosses and five mouthrinse solutions.

The costs were calculated to estimate monthly individual spending. For example, the monthly cost of a toothbrush was calculated by dividing the price of a toothbrush by three because this item should be replaced every three months ${ }^{7-8}$.

The toothpastes that were selected, were 'simple' pastes that only aim to fight dental caries (toothpastes with additional aims, such as whitening, herbal etc. were excluded) and only $90 \mathrm{~g}$ (net weight) tubes were included. The ideal amount of toothpaste per brushing was considered to be $0.5 \mathrm{~g}$, which adds up to $45 \mathrm{~g}$ per month, considering three brushings per day. Thus, it was estimated that half a tube was used per month.
Dental floss should be used after brushing (three times per day $)^{7,14}$. Considering that all of the selected dental flosses were in 50 meter packages and approximately $50 \mathrm{~cm}$ is used each time, the monthly consumption was estimated to be $45 \mathrm{~m}$ per individual.

For the mouthrinse solutions, $500 \mathrm{~mL}$ commercial presentations were selected. When used according to the manufacturer's recommendations ( $15 \mathrm{~mL}$ per day), monthly use adds up to $450 \mathrm{~mL}$.

Calculations of the monthly consumption were made and data recorded on an Excel spreadsheet and later analysed with descriptive and analytical statistics using SPSS (Statistical Package for Social Sciences, SPSS Inc, Chicago, USA) software, version 18.0.

\section{RESULTS}

Table 1 shows the minimum, mean and maximum monthly cost of oral hygiene for all of the items of the study, and their price variation. For the minimum cost, the cheapest products were used and for the maximum cost, the most expensive ones were used.

Table 2 shows the mean cost of the most popular oral care products and their variation, in relation to the MS in 2011 and 2013, in the city of Teresina (PI).

Table 1. Monthly cost and \% variation of oral care products, per individual. Teresina ( PI) , 2011-2013

\begin{tabular}{|c|c|c|c|c|c|c|}
\hline Product & & Toothbrush & Toothpaste & Dental floss & Mouth rinse solution & Total \\
\hline Quantity & & $1 / 3$ & $45 g$ & $45 \mathrm{~m}$ & $450 \mathrm{ml}$ & \\
\hline \multirow{2}{*}{ Minimum cost } & 2011 & 0.45 & 0.94 & 0.55 & 12.00 & 13.94 \\
\hline & 2013 & 0.38 & 0.68 & 3.5 & 14.40 & 18.96 \\
\hline Variation (\%) & & -16 & -28 & +636 & +17 & +24 \\
\hline \multirow{2}{*}{ Maximum cost } & 2011 & 4.00 & 8.00 & 6.00 & 19.00 & 37.00 \\
\hline & 2013 & 5.99 & 7.59 & 11.50 & 27.85 & 52.93 \\
\hline Variation (\%) & & +34 & -5.1 & +48 & +31.7 & +30 \\
\hline \multirow{2}{*}{ Mean cost } & 2011 & 0.53 & 0.71 & 3.40 & 13.00 & 17.93 \\
\hline & 2013 & 1.99 & 1.86 & 6.10 & 14.97 & 24.92 \\
\hline Variation (\%) & & +375 & +261 & +179 & +15.1 & +38 \\
\hline
\end{tabular}

Table 2. Impact of the mean monthly cost of oral care products in the city of Teresina (PI) on the Brazilian minimum wage

\begin{tabular}{|c|c|c|c|c|}
\hline \multirow{2}{*}{ Item } & \multirow{2}{*}{2011} & \multirow{2}{*}{2013} & \multicolumn{2}{|c|}{ Variation } \\
\hline & & & $R \$$ & $\%$ \\
\hline Minimum salary $(\mathrm{R} \$)$ & 620.00 & 678.00 & 58.00 & 9.35 \\
\hline Mean cost $(\mathrm{R} \$)$ & 17.93 & 24.92 & 6.99 & 38.98 \\
\hline$\%$ Impact of products on minimum salary & 2.88 & 3.67 & & 27.43 \\
\hline
\end{tabular}


The increase in the cost of oral care products was higher than the increase of the MS in the same study period.

\section{DISCUSSION}

No similar study to this one was found in the Brazilian literature. During the period of this study, the mean price of oral care products increased approximately three times more than the MS. Additionally, in 2011, an individual had to spend up to $2.88 \%$ of the MS to purchase all of the oral hygiene products, but in 2013 they had to spend $3.67 \%$ of the MS. Thus, the rate of increase of the oral care products was considered high.

Over the same period the increase in prices of products in general in 2011 was 6.5\% and in 2013 was $5.91 \%$, according to the Brazilian Institute of Geography and Statistics (IBGE), the National Broad Index of Prices for Consumers (IPCA). This index is calculated every month and the Brazilian government uses it to verify whether the prices of services and products meet the yearly inflation targets of the Brazilian Central Bank ${ }^{15}$.

In the Brazilian region where the study was carried out, $50 \%$ of the adolescents and young people between 16 and 24 years old who were working had an income lower than $0.5 \mathrm{MS}$ and $28.3 \%$ had an income between 0.5 and 1 MS per month in 2011. For the elderly above 60 years old, $9 \%$ earned up to $0.5 \mathrm{MS}$ and $52.5 \%$ earn ed between 0.5 and 1 MS in $2011^{16}$. These data make evident how the prices of the products can be a burden on a family's budget who survive on one MS. Therefore, it is unrealistic to expect that an individual with a monthly income of one MS and a family to support would consider it a priority to purchase a new toothbrush every three months, for example.

Despite scientific evidence that it is important to control dental biofilm to prevent oral diseases, oral health care products are commercially considered to be toiletries, not essential medications. However, because of their importance, public managers should categorise them as items essential for health or for the control of oral diseases. Each month a family's total monthly expenditure, on Health and Personal Care Products before December 31,2011 , was $10.76 \%$ and after January 1,2012 , it was $11.09 \%{ }^{15}$.

In Brazil, the high cost of oral care products prevents access for the majority of the population to what is considered the ideal method of maintaining a good level of oral hygiene. The fact that there was a trend for prices of oral care products to increase more than the minimum salary (in percentage terms) means that it is likely that individuals will find it even harder to purchase necessary oral care items if the situation carries on.

One of the limitations of this study was the fact that we had to restrict the number of products analysed. However, the best selling ones were included. It is estimated that Brazil has an annual consumption of 52 tons of toothpaste, 75 million toothbrushes and 1 billion meters of dental floss (Istoé/ Senhor, 1988; Odontonotícias , 1988, 1992). These data reveal how inadequate the consumption is, considering the population was 160 million people at the time ${ }^{17}$.

Periodic professional evaluations are also important because it is during the consultations that oral diseases can be diagnosed and treated with simple and easy procedures. Invariably the dentist will advise patients how to use a toothbrush, toothpaste, dental floss and, occasionally, mouth rinse solution.

Regular use of oral care products helps to prevent the onset and progression of diseases of the oral cavity $7-9,18$. However, due to the large number of products available and to the intensive marketing investment of some companies, the consumer can be led to believe that only the most sophisticated or expensive ones give good results $^{3}$. There is no scientific evidence to believe that expensive products are better. Scientific studies to compare the efficiency of oral health products with different costs should be designed.

\section{CONCLUSION}

The cost of the most frequently used oral health products has a high impact on a regular family's budget in Brazil and it increased proportionally more than the minimum salary between 2011 and 2013 in Teresina, Brazil.

Thus, dentists should be aware of the cost of oral hygiene items that they recommend and the financial impact that they might have on the regular family's budget.

\section{Collaborators}

TTB DUTRA participated in the writing and presentation of this manuscript. ALR SILVA and AM 
CABRAL participated in the experimental development, data collection and writing of the manuscript. JM MOITA Neto participated in the analysis and interpretation of data and writing of the manuscript. RR PRADO JÚNIOR participated in the design of the study and writing and editing of the manuscript.

\section{REFERENCES}

1. Petersen, PE. World Health Organization global policy for improvement of oral health - World Health Assembly 2007. Community Dent Oral Epidemiol. 2009 Feb;37(1):1-8. doi: 10.1111/j.1600-0528.2008.00448.x.

2. Brasil. Ministério da Saúde. Secretaria de Atenção à Saúde. Departamento de Atenção Básica. Projeto SB Brasil 2010: condições de saúde bucal da população brasileira 2002 2003: resultados principais. Brasília: Ministério da Saúde 2010 [citado 2014 Jul 20]. Disponível em:<http://bvsms. saude.gov.br/bvs/publicacoes/pesquisa_nacional_saude_ bucal.pdf>.

3. Brasil. Ministério da Saúde. Secretaria de Atenção à Saúde. Departamento de Atenção Básica. Projeto SB Brasil 2010: Pesquisa Nacional de Saúde Bucal - resultados principais [citado 2014 Jul 20]. Disponível em:< http://dab.saude.gov.br/CNSB/ sbbrasil/arquivos/projeto_sb2010_relatorio_final.pdf>.

4. Petersen PE. World Health Organization global policy for improvement of oral health - World Health Assembly 2007. Community Dent Oral Epidemiol. 2009 Feb;37(1):1-8. doi: 10.1111/j.1600-0528.2008.00448.x

5. Moynihan, P and Petersen, PE. Diet, nutrition and the prevention of dental diseases. Public Health Nutr. 2004;7(1A):201-26.

6. U.S. Public Health Service. Oral Health in America: a report of the surgeon general. In: U.S. Public Health Service. Community and other approaches to promote oral health and prevent oral disease. Rockville, MD: U.S. Public Health Service; 2000. p. 15588

7. Gebran MP, Geber APO. Controle químico e mecânico da placa. Fac Ciencias Bio \& Saúde. 2002;26(3):45-58.

8. Bass CC. An effective method of personal oral hygiene. J La State Med Soc. 1954;106 (2):57-73.

9. Bottan ER, Campo L, Odebrecht CMLR, Silveira EG, Schmitt P, Araújo SM. Critérios adotados para a escolha da escova dental: estudo com consumidores de Florianópolis, Santa Catarina (Brasil). RSBO. 2010;7(2):173-81.
10. Bratthall $D$, Hansel-Petersson $G$, Sundberg $H$. Reasons for the caries decline: what do the experts believe. Eur J Oral Sci. 1996; 104(4 (Pt 2)):416-22.

11. Cury JA. Dentifrícios: como escolher e como indicar. In: APCD (Org.). Odontologia. São Paulo: Artes Médicas; 2002. p. 281-95.

12. Maciel MPM. Relatório da Análise em escovas dentais para uso adulto e infantil. Rio de Janeiro: INMETRO; 2013 [citado 2014 Jul 20]. Disponível em:<http://www.inmetro.gov.br/consumidor/ produtos/escovas_dentais.pdf>.

13. Manfredini MA, Botazzo C. Tendências da indústria de equipamentos odontológicos no Brasil entre 1990 e 2002: notas prévias. Ciênc Saúde Coletiva. 2006;11(1):169-77. doi: $10.1590 /$ S1413-81232006000100025

14. Santo LF, Hirata E, Mialhe FL, Silva DD, Silva RP. Custo da higienização bucal no município de Cascavel. RFO UPF. 2008;13(2):12-6

15. Brasil. Ministério do Planejamento, Orçamento e Gestão. Instituto Brasileiro de Geografia e Estatística. Índice Nacional de Preços ao Consumidor Amplo [citado 2014 Jul 20]. Disponível em: <http://br.advfn.com/indicadores/ipca>

16. Brasil. Ministério do Planejamento, Orçamento e Gestão. Instituto Brasileiro de Geografia e Estatística. Síntese de indicadores sociais: uma análise das condições de vida da população brasileira. Rio de Janeiro: Instituto Brasileiro de Geografia e Estatística; 2012.

17. Cordon JA, Garrafa. Prevenção versus preventivismo. Sau \& Transf Soc. 2011;1(3):85-90

18. Sundell AL, Ullbro $C$, Koch $G$. Evaluation of preventive programs high caries active preschool children. Swed Dent J. 2013;37(1): 23-9. 
